\title{
STAKEHOLDERS, SOCIAL RESPONSIBILITY AND REMUNERATION PRACTICES IN THE MALAYSIAN TOURISM SMALL AND MEDIUM-SIZED ENTERPRISES
}

\author{
Nurhazani MOHD SHARIFF* \\ School of Tourism, Hospitality \& Event Management, COLGIS, Universiti \\ Utara Malaysiao6010, Sintok, Kedah, Malaysia, e-mail: hazani@uum.edu.my
}

\author{
Azlan ZAINOL ABIDIN \\ Tunku Puteri Intan Safinaz School, COB, Universiti Utara Malaysia \\ o6010, Sintok, Kedah, Malaysia, e-mail: azlan@uum.edu.my
}

\begin{abstract}
Citation: Mohd Shariff, N. \& Zainol Abidin, A. (2020). STAKEHOLDERS, SOCIAL RESPONSIBILITY AND REMUNERATION PRACTICES IN THE MALAYSIAN TOURISM SMALL AND MEDIUM-SIZED ENTERPRISES. GeoJournal of Tourism and Geosites, 29(2), 684-693. https://doi.org/10.30892/gtg.29224-499
\end{abstract}

\begin{abstract}
The tourism small and medium-sized enterprises play a vital role as the backbone in the Malaysian tourism industry, hence becoming a significant portion of entrepreneurial enterprises for the country. It is therefore essential for the enterprises to efficiently perform particularly in their managerial aspects. A study was conducted among 229 employees of the tourism small and medium-sized enterprises in Malaysia to investigate three major managerial practices namely, the stakeholders practice, the social responsibility practice and the remuneration practice in line with a better performance of the enterprises. The findings highlight that all three practices are considered as vital component in managing the tourism small and medium-sized enterprises. Majority of the respondents agreed that the stakeholders of the enterprises would establish fair procedures for goods and services based on considerations of quality, pricing and performance. Further, most of them also agreed that environmental management is essential as their social responsibility practice in the enterprises. Additionally, the findings indicate that most respondents found that the incentive of top management in the enterprises would ensure the alignment of the management and stakeholders' interest. The study significantly contribute to the tourism small and medium-sized enterprises in creating better management scenario within the enterprises in order to achieve strategic planning competitiveness in the industry.
\end{abstract}

Key words: Tourism, small and medium-sized enterprises, stakeholders, social responsibility, remuneration

\footnotetext{
* Corresponding author
} 


\section{INTRODUCTION}

The definition of small and medium-sized enterprise (SME) varies from country to country. Several guidelines exist to assist firms or organizations to better understanding of SME. In such country for example Egypt, SME is defined as having more than 5 and fewer than 50 employees (Dalberg, 2011). As for Vietnam, SME is considered as having employees between 10 and 300 in the organization. In further definition, the Inter-American Development Bank defines SME as having a maximum of 100 employees and less than $\$ 3$ million in revenue. According to Natarajan and Wyrick (2011), countries in Europe define SME as having manpower fewer than 250 employees while in the United States, SME is defined as those with employees less than 500 standard definition. Additionally, the World Bank (2002) defines SME as those enterprises with a maximum of 300 employees, $\$ 15$ million in annual revenue, and \$15 million in assets. For several countries such as Malaysia, Japan, Hong Kong and Thailand, SMEs are defined in various sectors to differentiate the SMEs' business activities such as manufacturing, wholesaling, retailing, agriculture and services.

This is because different sectors have different characteristics, particularly in terms of the number of employees. Most countries also use the number of employees to categorize the firms into small and medium sizes. However, the number of employees what makes up small and medium-sized firms differ across the countries. As for Malaysia, SMEs are defined by the National SME Development Council (NSDC) based on the number of full-time employees or the total sales or revenue.

In Malaysia, it is reported that many of the SMEs are in the services sector, with more than a third of the firms involved in the tourism industry in 2010 (Department of Statistics, 2012). The tourism small and medium-sized enterprises (TSMEs) make a significant portion of SMEs, and as a matter of fact play a big role as the backbone in Malaysia tourism industry. TSMEs in Malaysia offer tourism products and services, and have unique characteristics compared to tangible manufactured products.

The Malaysian government sees the potential of the tourism industry through its contribution to economic growth and social development hence it has taken a strategic approach to developing the performance of its tourism industry. As tourism emerged as one of the world's major industries with significant changes in the structure and operation of the tourism industry worldwide, the tourism products and services have engendered the need for tourism small and medium-sized enterprises (TSMEs) to develop strategies to become competitive in the changing global economy.

\section{Problem Statement}

Several studies note that TSMEs play important role in the industry as to achieve the significant changes in global tourist consumption, and the increase of differentiated and niche tourism products (Page et al., 1999; Getz \& Carlsen, 2005; Ateljevic, 2009). TSMEs performance and survival in the industry are particularly important to Malaysia because apart from their key role in delivering tourism products to the tourist, they also play an active role in advancing the local community.

Additionally, a report by the Small and Medium-Sized Enterprise Corporation Malaysia (2012) emphasized an increase percentage in the tourism industry from $21.1 \%$ to $41.1 \%$ of growth of overall SMEs in 2005 indicating a number of 100,637 firms to 239,110 firms. During the Sixth, Seventh and Eighth Malaysian Plans, the government has aggressively invested in the growth of TSMEs such as hotels and relevant tourism and recreation projects. The Economic Planning Unit (1996) report showed that the government investment in the Sixth Malaysian Plan 1991-1995 increased to RM8.8 billion 
while in the Seventh Malaysian Plan 1996-2000 increased to RM18.2 billion. In relation to the Seventh Malaysian Plan 1996-2000, the government spent RM484.2 million to the expansion of various range of tourism activities, products and marketing (Economic Planning Unit, 1996). Further, due to this aggressive action, the average hotel occupancy also increased by 55 per cent in 2000 with a number of SME hotels increased from 1,220 in 1996 to 1,492 in 2000. Given this phenomenon, the Malaysian government has made concerted efforts to spur the tourism industry through empowering and supporting TSMEs. It is believed that understanding the key success factors of TSMEs and at the same time recognizing the important of TSMEs are therefore pertinent to ensure TSMEs will reach their full potential. Further, to ensure TSMEs in Malaysia continue to support the national tourism industry and remain a source of employment to the community, the government has focused on determining the key success factors of Malaysian TSMEs' performance with a focus on tourism entrepreneurs' motivation and management. Malaysia has come out with various TSMEs programs and policies implemented by the government to promote the Malaysian tourism industry. As reported by the Small and Medium Enterprise Corporation Malaysia (2012), the government spent RM 4,677.1 million in the form of 183 training and financial programs for TSMEs in 2011, thus increasing the funding on the development allocation.

Additionally, the Malaysian government has also encouraged the active participation of TSMEs through vigorous promotion and marketing, diversifying target markets, as well as improving the competitiveness of tourism products and services in an effort to sustain tourists' interest in Malaysia. The TSMEs need to compete with other industries not just concerning the creation of a business plan but more of engaging in business networking and managing business performance.

Many studies emphasize the problems in managing TSMEs. For instance, the TSMEs are found to have a shortage of financial resources, lack of management and marketing skills, lack of industry expertise and strategic vision (Beaver et al., 1998; Boer, 1998; Dewhurst \& Horobin, 1998; Friel, 1998; Wanhill, 1998; Webster, 1998; Shaw \& Williams, 2002; Augustyn, 2004; Thomas \& Augustyn ,2007). A report from the Ministry of Tourism and Culture Malaysia highlighted that the tourism industry employs more than a third of employees in the services sector and is considered the second highest earner in foreign exchange and national income (MOTAC, 2011). Hence, the issue of corporate governance in TSMEs must be given serious attention. TSMEs in Malaysia employ about 991, 419 workers accumulate to 38.1 per cent of total employment in SMEs services sectors. Taking into account that TSMEs in Malaysia play significant role in the economic development of the country with 239,110 active establishments including 142,721 firms (59.7 per cent) offering food and beverage services, 40,025 firms (16.7 per cent) offering transportation services and other miscellaneous tourism services and 19,643 firms (8.2 per cent) offering accommodation services; arts, entertainment and recreation services; and travel agency, tour operator and tourism guide services, it is important to study the related issues concerning the managerial practices in TSMEs.

\section{Research Objective}

The primary objective of the study was to investigate the perceptions of TSMEs employees on the three managerial practices in the enterprise. The study embarked on the following questions:

1. What are the perceptions of TSMEs employees on the stakeholders practice in managing the enterprise? 
2. What are the perceptions of TSMEs employees on the social responsibility practice in managing the enterprise?

3. What are the perceptions of TSMEs employess on the remuneration practice in managing the enterprise?

\section{LITERATURE REVIEW}

Many studies have been conducted on different segments of SMEs in the tourism industry for instance constrained growth of the tourism sector, environmental goals of rural family-owned/-operated tourism, small business performance, financial performance, leadership and motivation behavior and family businesses. However, an intensive literature review also reveals that there have been very few studies on tourism entrepreneurship and small businesses in the tourism industry. This is probably due to the fact that entrepreneurs in the industries might possess lower levels of entrepreneurial characteristics compared to other industries. In fact, it is believed that entrepreneurs are not motivated by the desire to maximize economic gain. They often operate businesses with low levels of employment and their managerial decisions are often based on highly personalized criteria (Dewhurst \& Horobin, 1998). In the perspective of education, Matlovič and Matlovičová (2016) highlight that to create specific value for potential employees, organization must give vital attention to knowledge, skills and competences.

Additionally, several studies indicate that most tourism entrepreneurs begin TSMEs due to the low entry barrier in the industry (Morrison \& Thomas, 1999; Skokic \& Morrison, 2011; Brouder \& Eriksson, 2013; which gives them an opportunity to be part of the industry (Jaafar et al., 2011). Further, Mazzarol et al. (1999) and also Skokic and Morrison (2011) suggest that the owner-manager's socio-economic characteristics such as age, gender and education level also form a part of the obstacles that have a considerable effect on entrepreneurial intention and business performance of SMEs.

Tourism SMEs have to face many challenges just like other SMEs elsewhere are facing such as, a shortage of financial resources, lack of management and marketing skills, lack of industry expertise and strategic vision (Beaver et al., 1998; Boer, 1998; Dewhurst \& Horobin, 1998; Frie,l 1998; Wanhill, 1998; Webster, 1998; Shaw \& Williams, 2002; Augustyn, 2004; Thomas \& Augustyn, 2007).

TSMEs also play a crucial role in the tourism industry by delivering tourism products and services to the tourist, thus vigorous efforts have been made by the Malaysian government to utilize the advantages that TSMEs can offer (Page et al., 1999; Getz \& Carlsen, 2000; Ateljevic, 2009). There are various TSME programs and policies implemented by the government to promote the Malaysian tourism industry through TSMEs (Small and Medium Enterprise Corporation Malaysia, 2012). The government has placed high expectations on TSMEs to play their role as a vital component in increasing the country's foreign exchange earnings. Looking at the perspective of an entrepreneurial firm as SME, it is believed that there is a need to access resources for growth. They need inputs on business operations, good strategy and best practices in the industrial sector.

The three managerial practices in SMEs which are considered essential for managing the enterprises effectively have been studied by several researchers. Mohd. Shariff et al. (2018) had conducted a study to develop a framework of corporate governance best practice in TSMEs and noted that three out of nine elements in the framework are stakeholders, social responsibility and remuneration. According to Freeman et al. (2007), the central idea of the stakeholder theory is to manage and incorporate the relationship and welfare of shareholders, customers, suppliers, employees and other groups in a way that guarantees the organization's long-term 
success. Moreover, stakeholders such as expert and non-expert communities' perceptions are considered important to be taken into consideration not just in an organization but futher in marketing a brand image of a destination (Matlovičová \& Kormaníková, 2014). In fact, a study by Jaswadi et al. (2015) emphasized that stakeholders play important aspect in encouraging the growth and sustainability of SME in Indonesia. Hence, the stakeholder practices should be applied in managing the TSMEs. Additionally, Wood and Gray (1991) suggest the collaboration between stakeholders and other groups are important as the dimension could explain the success of the dynamic interactions between SMEs and their stakeholders, through which the stakeholders try to influence the SMEs' operations system.

The corporate social responsibility in SMEs was critically studied by Bikefe et al. (2020) by investigating 62 articles in the published journals. The study focused on the implementation of the social responsibility activities as to improve the governance of SMEs. A similar study was conducted by Maldonado-Erazo et al. (2020) using more articles on corporate social responsibility in SMEs. Their study reviewed 277 related articles and found that corporate social responsibility can result in an action that enriches the company by obtaining economic returns and at the same time increases its competitiveness in the market. The social responsibility practice is somehow observed in previous study as factor which show a direct relationship between the firms' sizes (Leóna et al., 2017). More, social responsibility practices are likely to be established by the managers of micro and small enterprises compared to the medium-sized enterprises. Edwards (2018) emphasized that corporate social responsibility activities are important to improve corporate image and competitiveness of the SMEs, hence, SMEs need to communicate their corporate social responsibility in their governance mechanisms.

Several studies have been conducted to determine the importance of remuneration practices in company particularly SMEs. Remuneration practice is believed will enhance productivity, quality and financial performance of the firm's (Birasnav \& Rangnekar, 2009). Additionally, remuneration is also concluded as one of the most important human resource practices and by adopting the compensation practice organizational performance can be increased (Khan \& Khan, 2012). In the context of destination development, a study by Klimovský et al. (2016) found that the amount of money spent had significant relationship with the characteristics of access to education, basic infrastructure and healthcare. Similarly, Subramanian et al. (2011) note in their study undertaken in Malaysian SMEs that proper compensation or remuneration policies will increase the employee and organization's performance. Hence this fact indicated the vital role played by remuneration practice in determining the enterprise's success.

\section{METHODOLOGY}

The secondary data in the study was obtained from various sources extensively from the Ministry of Tourism and Culture Malaysia (MOTAC), Tourism Malaysia, and SME Corporation located in Putrajaya and Kuala Lumpur, Malaysia. As for the primary data, the study used questionnaire survey where the information was obtained and compiled with the purpose of investigating the perceptions of TSMEs top management on the three managerial practices in managing the company. According to Sekaran and Bougie (2010), survey questionnaire is an efficient data collection mechanism to ensure relevancy and consistency of information gathered as the responses are objective, standardized and comparable. Additionally, the questionnaire was designed and presented in simple and unbiased wordings. The purpose was to make sure that the respondents can easily understand the questions and provide answer based on their own perception (Zikmund et 
al., 2010). 229 employees of the Malaysian TSMEs were selected as respondents. The questionnaire consisted of two parts namely part one asking the respondents to describe their profiles and part two asking them to indicate their perceptions on the three managerial practices in the company namely the stakeholders practice, the social responsibility practice and the remuneration practice. The information and data were then analyzed using Statistical Package for Social Science version 19.0 (SPSS). Descriptive statistics were employed to describe the respondents' profiles and perceptions.

\section{FINDINGS}

Table 1 indicates that majority of the respondents were top management of the TSMEs (80.0\%). Majority of them were also female (54.6\%) and the remaining were male (45.4\%). The findings further indicate that most of them were also below 30 years old $(46.3 \%)$, it then follows by $30-50$ years old $(42.8 \%)$ and only few of the respondents were below 50 years old (10.9\%). As for the level of education, most respondents stated as having diploma (39.7\%). Some of them also were categorized as undergraduate (30.6\%) and only few had postgraduate degree (3.5\%).

Table 1. The respondents' profile

\begin{tabular}{|c|c|c|c|}
\hline Items & Frequency & Percent & Cumulative Percent \\
\hline \multicolumn{4}{|l|}{ Position: } \\
\hline Top management & 184 & 80.3 & 80.3 \\
\hline Others & 45 & 19.7 & 100.0 \\
\hline \multicolumn{4}{|l|}{ Gender: } \\
\hline Male & 104 & 45.4 & 45.4 \\
\hline Female & 125 & 54.6 & 100.0 \\
\hline \multicolumn{4}{|l|}{ Age: } \\
\hline Below 30 years old & 106 & 46.3 & 46.3 \\
\hline $30-50$ years old & 98 & 42.8 & 89.1 \\
\hline Above 50 years old & 25 & 10.9 & 100.0 \\
\hline \multicolumn{4}{|l|}{ Level of education: } \\
\hline School certificate & 42 & 18.3 & 18.3 \\
\hline Diploma & 91 & 39.7 & 58.0 \\
\hline Undergraduate & 70 & 30.6 & 88.6 \\
\hline degree & 18 & 7.9 & 96.5 \\
\hline Postgraduate degree & 8 & $3 \cdot 5$ & 100.0 \\
\hline \multicolumn{4}{|c|}{ Number of years working: } \\
\hline Less than 5 years & 98 & 42.8 & 42.8 \\
\hline $5-10$ years & 86 & 37.6 & 80.4 \\
\hline More than 10 years & 45 & 19.6 & 100.0 \\
\hline \multicolumn{4}{|l|}{ Company founded: } \\
\hline Before 1980 & 19 & 8.3 & 8.3 \\
\hline $1981-1991$ & 26 & 11.4 & 19.7 \\
\hline $1992-2002$ & 91 & 39.7 & 59.4 \\
\hline $2003-2016$ & 93 & 40.6 & 100.0 \\
\hline \multicolumn{4}{|l|}{ Number of workers: } \\
\hline Less than 30 & 114 & 49.8 & 49.8 \\
\hline $30-99$ & 67 & 29.3 & 79.1 \\
\hline $100-200$ & 33 & 14.4 & 93.5 \\
\hline More than 200 & 15 & 6.6 & 100.0 \\
\hline
\end{tabular}

Additionally, the findings of the survey highlights that majority of the respondents had been working in the company for less than 5 years $(42.8 \%)$, follows by 
$5-10$ years (37.6\%) and the others stated as more than 10 years (19.6\%). Most of the TSMEs were founded in year $2003-2016$ and having less than 30 workers $(49.8 \%)$.

Table 2. Perceptions on the stakeholders practice

\begin{tabular}{|l|c|c|}
\hline \multicolumn{1}{|c|}{ Items } & Agree (\%) & Mean \\
\hline $\begin{array}{l}\text { The enterprise will establish fair procedures for goods and } \\
\text { services based on considerations of quality, pricing and } \\
\text { performance. }\end{array}$ & 86.0 & 4.074 \\
\hline $\begin{array}{l}\text { The enterprise is to establish mechanisms for passing } \\
\text { benefits along to the surrounding community. }\end{array}$ & 85.2 & 4.079 \\
\hline $\begin{array}{l}\text { The enterprise is to institute mechanisms designed to ensure } \\
\text { the fair treatment of the employees. }\end{array}$ & 84.8 & 4.153 \\
\hline $\begin{array}{l}\text { The enterprise is to establish mechanisms for monitoring } \\
\text { compliance with laws and regulations governing its line of } \\
\text { business. }\end{array}$ & 84.0 & 4.079 \\
\hline $\begin{array}{l}\text { The enterprise will establish mechanisms for allowing its } \\
\text { customers to make inquiries, suggestions and claims. }\end{array}$ & 82.5 & 3.952 \\
\hline $\begin{array}{l}\text { The stakeholders practice plays vital role in managing the } \\
\text { enterprise effectively. }\end{array}$ & 81.6 & 4.031 \\
\hline
\end{tabular}

\section{Perceptions on the stakeholders' practice}

Table 2 depicts the findings of the study regarding respondents' perceptions on the stakeholders practice in TSMEs. The findings indicate that all the six items in this aspect produced high mean value ranged from 3.952 to 4.153 . Most of the respondents agreed that the enterprise will establish fair procedures for goods and services based on considerations of quality, pricing and performance (86.0\%). They also agreed that the role of the enterprise is to establish mechanisms for passing benefits along to the surrounding community (85.2\%). Additionally, the findings show that majority of the respondents also agreed that the institute mechanisms designed to ensure the fair treatment of the employees (84.8\%). They believed that the purpose of the enterprise is to establish mechanisms for monitoring compliance with laws and regulations governing its line of business (84.0\%). Further, the findings indicate that the respondents agreed the enterprise will establish mechanisms for allowing its customers to make inquiries, suggestions and claims (82.5\%) and finally, they believed that the stakeholders practice plays vital role in managing the enterprise effectively (81.6\%).

Table 3. Perceptions on the social responsibility practice

\begin{tabular}{lcc}
\hline \multicolumn{1}{c}{ Items } & Agree (\%) & Mean \\
\hline $\begin{array}{l}\text { The enterprise will promote sound environmental } \\
\text { management and help control the environmental impact of }\end{array}$ & 86.9 & 4.158 \\
$\begin{array}{l}\text { their operations, products and services. } \\
\begin{array}{l}\text { The enterprise will need to develop strategies for preventing } \\
\text { and minimizing environmental and human impacts and risks. }\end{array}\end{array}$ & 86.4 & 4.070 \\
$\begin{array}{l}\text { Social responsibility is a vital practice in managing the } \\
\text { enterprise effectively. }\end{array}$ & 83.8 & 4.118 \\
\hline
\end{tabular}

\section{Perceptions on the social responsibility practice}

Table 3 depicts the findings from the analysis pertaining to the social responsibility practice in the TSMEs. The findings highlight that three items in the practice derived with high mean value ranged from 4.070 to 4.158. Majority of the respondents agreed that the enterprise will promote sound environmental management 
and help control the environmental impact of their operations, products and services (86.9\%). This is followed by the enterprise will need to develop strategies for preventing and minimizing environmental and human impacts and risks (86.4\%).

Further, the respondents also agreed that the social responsibility is a vital practice in managing the enterprise effectively (83.4\%).

Table 4. Perceptions on the remuneration practice

\begin{tabular}{lcc}
\hline \multicolumn{1}{c}{ Items } & Agree (\%) & Mean \\
\hline $\begin{array}{l}\text { The incentives of top management ensure the alignment of the } \\
\text { management and shareholders interest. }\end{array}$ & 80.3 & 3.974 \\
$\begin{array}{l}\text { The director's remuneration should be appreciable and reflect the } \\
\text { responsibility and commitment of the directors. }\end{array}$ & 78.6 & 4.004 \\
Remuneration is a vital practice in managing the enterprise effectively. & 78.1 & 3.978 \\
\hline
\end{tabular}

\section{Perceptions on the remuneration practice}

The study also investigated the respondents' perceptions on the remuneration practice in the TSMEs (Table 4). The findings indicate that all the three items in this practice produced high mean value ranged from 3.974 to 4.004. Majority of the respondents agreed that the incentives of top management ensure the alignment of the management and shareholders interest (80.3\%). The respondents also agreed that the director's remuneration should be appreciable and reflect the responsibility and commitment of the directors (78.6\%). Finally, most of them found that remuneration is a vital practice in managing the enterprise effectively (78.1\%).

\section{DISCUSSION AND CONCLUSION}

Generally, the findings of the study regarding the three managerial practices in the TSMEs highlight that the stakeholders, social responsibility and remuneration practices are vital in managing the TSMEs effectively. Hence, these practices are believed by the employees of the TSMEs could lead to the successful of the enterprise.

The findings are also in line with the previous studies where the stakeholders are claimed to provide greater accountability not just in managing such company but also on the sustainability issues related to the company (Raja Mohd Rasi et al., 2014; Mohd Shariff et al., 2018; Bikefe et al., 2020; Maldonado-Erazo et al., 2020).

Further, the findings are consistent to the current study by Leóna et al. (2017) where they reveal that the establishment of social responsibility programs could promote and support responsible initiatives particularly in the micro SMEs.

The study is also in line with previous studies by Edwards (2018), Bikefe et al. (2020) and Maldonado-Erazo et al. (2020) regarding corporate social responsibility as factor determining the competitiveness of SMEs. Additionally, remuneration is also considered as a vital practice in the SMEs as it will enhance productivity, quality and financial performance of the company (Birasnav \& Rangnekar, 2009) and further is seen as the factor that increase the company's productivity (Zakaria et al., 2011). Moreover, the study supports the findings from Jaswadi et al. (2015) where they found that stakeholders such as management board and supervisors can provide governance mechanisms in SME through the adaptation of good governance.

The study has significantly highlighted the importance of the stakeholders, social responsibility and remuneration practices in managing the Malaysian TSMEs effectively. However, there is still a limitation of the study such as it only focused on the three managerial practices in their organizations. Hence, further research should be conducted 
to investigate the significance of these practices and also studying other significant practices which may provide greater impacts to the success of the Malaysian TSMEs. The findings would assist the TSMEs employees particularly the top management in managing TSMEs effectively. Vital attention given to the three managerial practices namely the stakeholders, social responsibility and remuneration would significantly provide positive impacts of managing TSMEs in line with the growth of tourism industry.

\section{Acknowledgements}

The study was sponsored by the Malaysian Ministry of Higher Education under the Fundamental Research Grant Scheme (FRGS) S/O code 13028.

\section{REFERENCES}

Ateljevic, J. (2009). Tourism entrepreneurship and regional development: example from New Zealand. International Journal of Behaviour \& Research, 15(3), 282-308.

Augustyn, M.M. (2004). Coping with resource scarcity: the experience of UK Tourism SMEs. (Rhodri Thomas Editor), Small firms in tourism: international perspectives, Amsterdam:Elsevier, 257-275.

Bikefe, G., Zubairu, U., Araga, S., Maitala, F., Ediuku, E., \& Anyebe, D. (2020). Corporate social responsibility by small and medium enterprises (SMEs): a systematic review, Small Business International Review, 4(1), 16-33.

Beaver, G., Lashley, C., \& Stewart, J. (1998). Management development. (Rhodri Thomas Editor), The management of small tourism and hospitality firms, London:Cassell, 156-173.

Birasnav, M., \& Rangnekar, S. (2009). Structure of human capital enhancing human resource management practices in India. International Journal of Business and Management, 4 (5), 226-238.

Boer, A. (1998). An assessment of small business failure. (Rhodri Thomas Editor), The management of small tourism and hospitality firms. London:Cassell, 39-57.

Brouder, P., \& Eriksson, R.H. (2013). Staying power: what influences micro-firm survival in tourism? Tourism Geographies, 15(1), 125-144.

Dalberg (2011). Support to SME in developing countries through financial intermediaries. A Report Prepared by Dalberg Global Development Advisors.

Dewhurst, P., \& Horobin, H. (1998). Small business owners. (Rhodri Thomas Editor), The management of small tourism and hospitality firms, London:Cassell.

Edwards, C. (2018). Your small business needs a corporate social responsibility report. https://www. businessnewsdaily.com/10909-corporate-social-responsibility-reportingsmall-business.html

Freeman, R.E., Harrison, J.S., \& Wicks, A.C. (2007). Managing for stakeholders: survival, reputation, and success, New Haven, CT: Yale University Press.

Friel, M. (1998). Marketing. (Rhodri Thomas Editor), The management of small tourism and hospitality firms, London: Cassell, 117-137.

Getz, D., \& Carlsen, J. (2000). Characteristics and goals of family and owner-operated businesses in the rural tourism and hospitality sectors. Tourism Management, 21, 547-560.

Jaafar, M., Abdul-Aziz, A.R., Maideen, S.A., \& Mohd, S.Z. (2011). Entrepreneurship in the tourism industry: issues in developing countries. International Journal of Hospitality Management, doi:10.1016/j.ijhm.2011.01.0o3.

Jaswadi, Mohammad Iqbal \& Sumiadji, (2015). SME governance in Indonesia: a survey and insight from private companies, Procedia Economics \& Finance, 31, 387-398.

Khan, N.R., \& Khan, M.R. (2012). Human resource practices in SME sector: an exploratory case study of Pakistan. Euro Economica, 3(31), 17-19.

Klimovský, D., Želinský, T., Matlovičová, K., \& Mušinka, A. (2016). Roma settlements and poverty in Slovakia: different policy approaches of the state, local governments, and NGOs. Anthropological Notebooks, 22 (1), 23-42.

Leóna, G., Gutiérrezb, H.L.B., \& Farreroc, J.M.C. (2017). Evaluation of the perception and application of social responsibility practices in micro, small and medium companies in Barranquilla. an analysis from the theory of stakeholders. Estudios Gerenciales, 33, 261-270

Maldonado-Erazo, C. P., Álvarez-García, J., Cruz del Río-Rama, M., \& Correa-Quezada, R. (2020). Corporate social responsibility and performance in SMEs: scientific coverage, Sustainability, 12(2332), 2-26.

Matlovic, R. \& Matlovicova, K. (2016). The position of tourism and territorial marketing in the context of paradigmatic change to tertiary geography education in Slovakia. Geojournal of Tourism and Geosites, $18(2), 133-144$. 
Matlovičová K., \& Kormaníková J. (2014). City brand-image association detection. Case study of Prague. SGEM International Multidisciplinary Scientific Conferences on Social Sciences and Arts, SGEM 2014, Psychology \& Psychiatry, Sociology \& Healthcare, Education, Conference Proceedings, Volume II., Sociology and Healthcare, Albena, Bulgaria, ISBN 978-619-7105-23-0, ISSN 2367-5659, pp. 139-146

Mazzarol, T., Volery, T., Doss, N., \& Thein, V. (1999). Factors influencing small business start-ups. International Journal of Entrepreneurial Behaviour \& Research, 5(2), 48-63.

Mohd Shariff, N, Zainol Abidin, A, \& Bahar, M.R. (2018). Developing a framework of corporate governance best practice for the Malaysian tourism small and medium-sized enterprises. Geojournal of Tourism and Geosites, 22(2), 447-454.

Morrison, A., \& Thomas, R. (1999). The future of small firms in the hospitality industry. International Journal of Contemporary Hospitality Management, 11(4), 148-154.

Natarajan, G.S., \& Wyrick, D.A. (2011). Framework for implementing sustainable practices in SMEs in the United States. Proceedings of the World Congress on Engineering 2011 Vol I. WCE 2011, July 6 - 8, 2011, London, U.K.

Page, S.J., Forer, P., \& Lawton, G.R. (1999). Small business development and tourism: terra incognita? Tourism Management, 20, 435-459.

Raja Mohd Rasi, R.Z., Abdekhodaee, A., \& Nagarajah, R. (2014). Stakeholders' involvements in the implementation of proactive environmental practices linking environmental practices and environmental performances in SMEs. Management of Environmental Quality: An International Journal, 25 (2), 132-149.

Sekaran, U., \& Bougie, R. (2010). Research method for business: a skill building approach (5 $5^{\text {th }}$ edition). West Sussex, UK: John Wiley \& Sons Ltd.

Shaw, G., \& Williams, A. M. (2002). Critical issues in tourism: a geographical perspective. 2nd ed. Oxford: Blackwell Publishers.

Skokic, V., \& Morrison, A. (2011). Conceptions of tourism lifestyle entrepreneurship: transition economy context. Tourism Planning and Development, 8(2), 157-169.

Subramanian, C., Ibrahim, H., \& Mohd Shamsudin, F. (2011). Linking human resource and organizational performance: evidence from small and medium organizations in Malaysia. Jurnal Pengurusan 32, 27-37.

Thomas, R., \& Augustyn, M. M. (2007). Small firms in the New Europe: key issues, conclusions and recommendations. (Marcjanna M. Augustyn \& Rhodri Thomas Editors), Tourism in the New Europe, Oxford: Elsevier, 227-236.

Wanhill, S. (1998). Government organizations. (Cooper Chris, John Fletcher, David Gilbert, Rebecca Shepherd \& Stephen Wanhill Editors), Tourism - principles and practice, Harlow: Pearson Education Limited, 225-246.

Webster, M. (1998). Strategies for growth. (Rhodri Thomas Editor), The management of small tourism and hospitality firms, London:Cassell, 207-216.

Wood, D.J., \& Gray, B. (1991), Toward a comprehensive theory of collaboration. Journal of Applied Behavioral Science, 27 (2), 139-162.

Zakaria, N., Mohamed Zainal, S.R., \& Mohd. Nasurdin, A. (2011). Investigating the role of human resource management practices on the performance of SMEs: A conceptual framework. Journal of Global Management, 3 (1), 74-91.

Zikmund, W.G., Banin, B.J., Carr, J.C \& Griffin, M. (2010). Business research methods (8 ${ }^{\text {th }}$ edition.) USA: South-Western Publishing Company.

*** Department of Statistics Malaysia. (2012). Economic census 2011 - profile of small and medium enterprises. http://www.statistics.gov.my/portal/index.php?option

*** Economic Planning Unit (1996). A report of Malaysia economy. http://www.epu.gov.my

*** MOTAC (2011). Ministry of Tourism and Culture Malayia Report. www.motac.gov.my

*** Small and Medium Enterprises Corporation Malaysia (2012). Report on SMEs in Malaysia. www.smecorp.gov.my.

*** World Bank Report (2002). The international bank for reconstruction and development: building institutions for markets, New York, NY: Oxford University Press.

Submitted:

14.11.2018
Revised:

28.04.2020
Accepted and published online 08.05.2020 